\title{
Seasonal Toxicity Assessment of Oblong Blowfish (Takifugu oblongus) from Tamil Nadu Coast, India
}

\author{
S. M. Indumathi, Samanta Sekhar Khora* \\ VIT University, Vellore, Tamil Nadu, India.
}

\begin{tabular}{|c|c|}
\hline ARTICLE INFO & ABSTRACT \\
\hline $\begin{array}{l}\text { Article history: } \\
\text { Received on: 06/01/2017 } \\
\text { Accepted on: } 19 / 02 / 2017 \\
\text { Available online: } 30 / 03 / 2017\end{array}$ & $\begin{array}{l}\text { Food intoxications by pufferfishes have been reported all over the world producing several deaths every year } \\
\text { and toxicological profiling of various species of pufferfishes is crucial to avoid potential health hazards imposed } \\
\text { by ingestion of them. The present study is focussed to assess the toxicity of the pufferfish Takifugu oblongus, } \\
\text { from the coast of Tamil Nadu, India, in different seasons. The toxicity was evaluated by mouse bioassay using } \\
\text { Swiss Albino mice which is expressed in mouse units (MU/g). Anatomical changes were observed which is }\end{array}$ \\
\hline $\begin{array}{l}\text { Key words: } \\
\text { Acute Toxicity, Food } \\
\text { Intoxications, } \\
\text { Histopathology, Mouse } \\
\text { Bioassay, Pufferfish, } \\
\text { Takifugu oblongus. }\end{array}$ & $\begin{array}{l}\text { followed by histopathology of the dead mice tissues to prove the toxicity. The toxicity of liver was at its } \\
\text { maximum during the pre-monsoon season with } 163 \mathrm{MU} / \mathrm{g} \text { and skin showed least toxicity with } 75.88 \mathrm{MU} / \mathrm{g} \text {. } \\
\text { Post-monsoon season results showed that gonads proved maximum toxicity with } 249.06 \mathrm{MU} / \mathrm{g} \text {, while skin } \\
\text { showed lowest toxicity with } 89.34 \mathrm{MU} / \mathrm{g} \text {. Histopathology analysis of the dead mice showed various } \\
\text { inflammations and degenerations in the brain, heart, liver and kidneys. The toxicity of the pufferfish followed a } \\
\text { seasonal pattern differing in various seasons. The present study evidently proved that } T \text {. oblongus is highly toxic } \\
\text { and consumption of the same can pose serious dangers of health hazards and possibility of lethality to humans. }\end{array}$ \\
\hline
\end{tabular}

\section{INTRODUCTION}

Marine Ecosystem remains the habitat of organisms from various phyla amidst which fishes are the most diversified group. Several toxic marine organisms are reported till date and fishes have exhibited toxicity at extremities. The coastline of the Bay of Bengal and Arabian Sea continues to be a rich fishing ground in the South Asian region and India is one of the world's largest marine natural products' nations. The south east coast of India extends its coastal waters from the state of Tamil Nadu to Odisha. Among the wide varieties of fishes found in these waters, the pufferfishes form reasonable quantities. The pufferfishes belong to the family Tetraodontidae which includes 189 species in 28 genera (Veeruraj et al., 2011). Pufferfishes produce a potent neurotoxin named Tetrodotoxin (TTX) which is a sodium channel blocker in cell membranes. Reports indicated that TTX is much similar to saxitoxin (STX), which causes paralytic shellfish poisoning (How et al., 2003).

* Corresponding Author

Samanta Sekhar Khora, VIT University, Vellore, Tamil Nadu, India.

E-mail: sskhora@vit.ac.in
Consumption of these pufferfishes had produced food intoxications including numerous deaths worldwide viz, Mexico, USA, Hong Kong, Japan, Korea, Taiwan, Malaysia, Bangladesh and even India is not spared (Lange., 1990; Ghosh et al., 1993; Yang et al., 1996; Loke et al., 1997; Yoshikawa et al., 2000; Vazquez et al., 2000). Pufferfish poisoning kills approximately 20100 people annually, in Japan as reported by Yamashita et al. (2000) and Narahashi et al. (2001). Ingestion of the cooked roe of Chelenodon patoca produced numerous deaths and it was the first report of pufferfish poisoning in India reported by Jones in 1956. The toxicity of pufferfishes vary based on varied species, sex, season of collection, geographical location, and anatomical distribution as well (Matsui et al., 1998; Few et al., 1998; Yu et $a l ., 2002)$. In India, occurrence of pufferfish poisoning is sporadic, yet documenting toxicological profiles of the pufferfishes is still inadequate. Dating back, few species of pufferfishes were assessed for toxicity from the Bengal Coast of India. Research on pufferfishes from southern parts of India is lacking. Takifugu oblongus (Bloch, 1786), commonly called the Lattice Blassop or Oblong Blowfish is one among the available species of pufferfish along the Indian coast. 
Nevertheless, the toxicity of this species has been reported elsewhere, Lattice Blassop is considered a delicacy in most of the countries (Chew et al., 1983; Mahmud et al., 1999). $T$. oblongus was a disaster to Bangladesh in the years 1998 and 2002 causing several deaths due to its toxin (Mahmud et al., 1999; Ahmed., 2006; Homaira et al., 2010). This study was undertaken to analyse the toxicity of the pufferfish Takifugu oblongus collected from the coast line of Tamil Nadu using Swiss albino mice.

\section{MATERIALS AND METHODS}

\section{Specimen Collection}

Specimens were collected from Kasimedu fishing harbour, Chennai, Parangipettai coast in Chidambaram and Mandapam coast in Rameswaram in three seasons viz., Premonsoon, Monsoon and Post-monsoon. A total of 67 specimens were collected during all the seasons but monsoon season showed no availability of samples. The specimens were tightly packed, transferred in Icebox to the Medical Biotechnology Lab, VIT University and they were maintained in a deep freezer at $-20{ }^{\circ} \mathrm{C}$ until use.

\section{Experimental Animals}

Male Swiss albino mice weighing between 18-22 $\mathrm{g}$ were issued by and maintained in the Animal House, VIT University for experimentation. The study had strictly followed the guidelines of Committee for the Purpose of Control and Supervision on Experiments on Animals (CPCSEA). The experimental procedures followed, were approved by the Institutional Animal Ethical Committee (IAEC), VIT University (Registration No: 197/BC/06/CPCSEA). Chloroform was used as an anaesthetic agent for control mice before dissections and handling of mice was done ethically to reduce pain and suffering.

\section{Preparation of the toxic extracts}

The specimens were dissected and the organs particularly Skin, Muscle, Liver and Gonads were excised from which the extract was prepared. $10 \mathrm{~g}$ of every organ is weighed and separately homogenized in tissue homogenizer with $50 \mathrm{ml}$ of $0.1 \%$ Acetic acid in water. The tissue homogenates were boiled for 10 minutes in water bath at $50{ }^{\circ} \mathrm{C}$. They were cooled and centrifuged at $3000 \mathrm{rpm}$ for 10 minutes. The supernatants were collected and stored. The same procedure was followed thrice and the supernatants collected were combined, filtered and stored (Khora, 1991).

\section{Mouse Bioassay}

Mouse bioassay is the standard procedure for basic toxicity assessments.15 Male Swiss albino mice weighing between 18-22 g were used for standard Mouse Bioassay. The mice were separated into 5 groups, with each group having 3 mice. First group is maintained as Control, $2^{\text {nd }}$ group is injected with Liver extract, $3^{\text {rd }}$ with Skin extract, $4^{\text {th }}$ with Muscle extract and $5^{\text {th }}$ with Gonads extract. The control group receives $1 \mathrm{ml}$ of $0.1 \%$ acetic acid. $1 \mathrm{ml}$ of the each extract (undiluted) was injected into groups of mice split accordingly. If the mice die before 4 minutes, the extracts were diluted with $5 \mathrm{mg} / \mathrm{ml}$ Phosphate buffered saline (PBS). The injected mice were observed for toxicity symptoms and death for few minutes (Hollingworth et al., 1990). The toxicity of the extracts in Mouse Units (MU g-1) were calculated by the dose-death time relationship, where $1 \mathrm{MU}$ is defined as the amount of toxin (approximately $0.22 \mu \mathrm{g}$ ) required to kill a $20 \mathrm{~g}$ male mouse of ddY strain within 30 minutes of injection (Ghosh et al., 2004).

\section{Histopathological Examination}

Brain, heart, liver and kidneys of the mice which died followed by injection of the toxic extracts were excised to ascertain the toxicity of T. oblongus. They were fixed in $10 \%$ formalin for 24h and processed further (Lefkowitch, 1987). Tissue sections were prepared for each organ, followed by Hematoxylin and Eosin (H\&E) staining which is observed under light microscope and photographed.

\section{RESULTS}

\section{Mouse Bioassay}

As a result of mouse bioassay, the toxicity of the pufferfish Takifugu oblongus was determined. Muscles of the pufferfish showed no toxicity symptoms in the injected mice. In the pre-monsoon season, the maximum toxicity of the liver was found to be $163 \mathrm{MU} / \mathrm{g}$, gonads were $143.33 \mathrm{MU} / \mathrm{g}$, and skin was $75.88 \mathrm{MU} / \mathrm{g}$. Whereas, an increase in toxicity was noticed in the pufferfish during the post-monsoon season. Gonads showed maximum toxicity with $249.06 \mathrm{MU} / \mathrm{g}$, followed by the liver with 201.9 MU/g and skin with $89.34 \mathrm{MU} / \mathrm{g}$. The degree of toxicity was also analysed with the calculated mouse units (MU).

\section{Gross physiological and anatomical observations}

The injected mice showed intense hyper activity by running inside the cage in an excited manner, escape reaction, shivering of the forelimbs, paralysis of the hind limbs, paleness of the tail, diarrhoea and were suffocating until its final gasping breath. Upon autopsy, blood clots were found in the anterior visceral parts. Dark discoloration was noticed in the heart and liver. These observations were further supported by the histopathological changes.

\section{Histopathology \\ Control}

The control mice injected with $0.1 \%$ acetic acid showed no notable changes in either of the organs viz, brain, heart, liver and kidneys in both pre and post-monsoon seasons (Figures $1 \mathrm{a}, \mathrm{b}$, d \& d). 


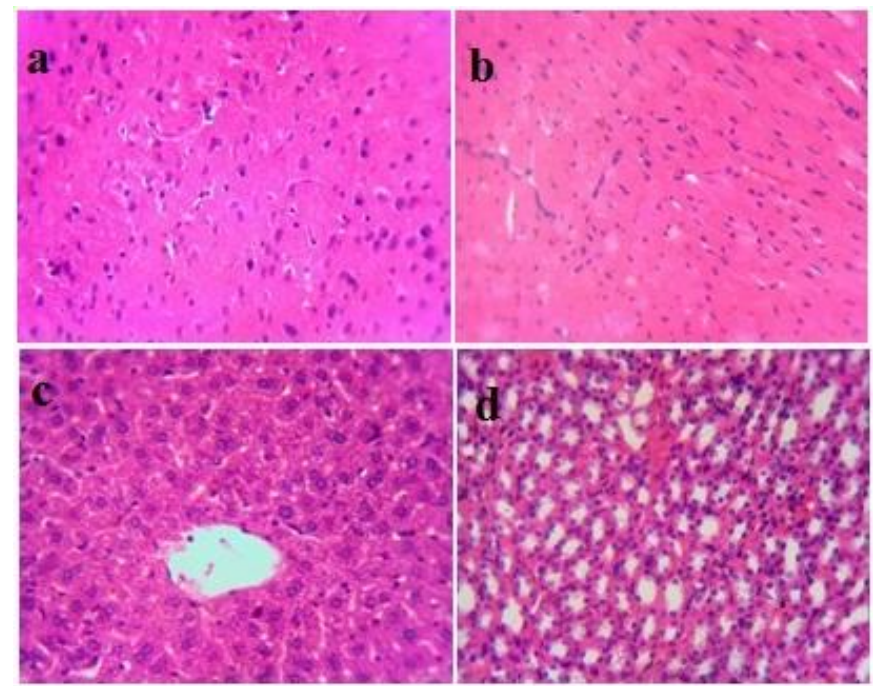

Fig. 1: Control Mice Images (H\&E X400).

a. No prominent changes (Brain) $1 \mathrm{~b}$. No prominent changes (Heart) 1c. No prominent changes (Liver) 1d. No prominent changes (Kidneys)

\section{Pre-monsoon Observations Effects of Liver Extract}

Gliosis was observed in the brain of mice (Figure $2 \mathrm{a}$ ). Heart tissues showed arrangement of cardiomyocytes in synctial pattern and neither inflammations, nor infections were found (Figure 2b). Mild sinusoidal dilation and inflammations were found in the liver of mice (Figure 2c). Glomeruli with congestion and they are surrounded by closely packed tubules, lined by cuboidal epithelium were observed in the mice kidneys (Figure 2d).
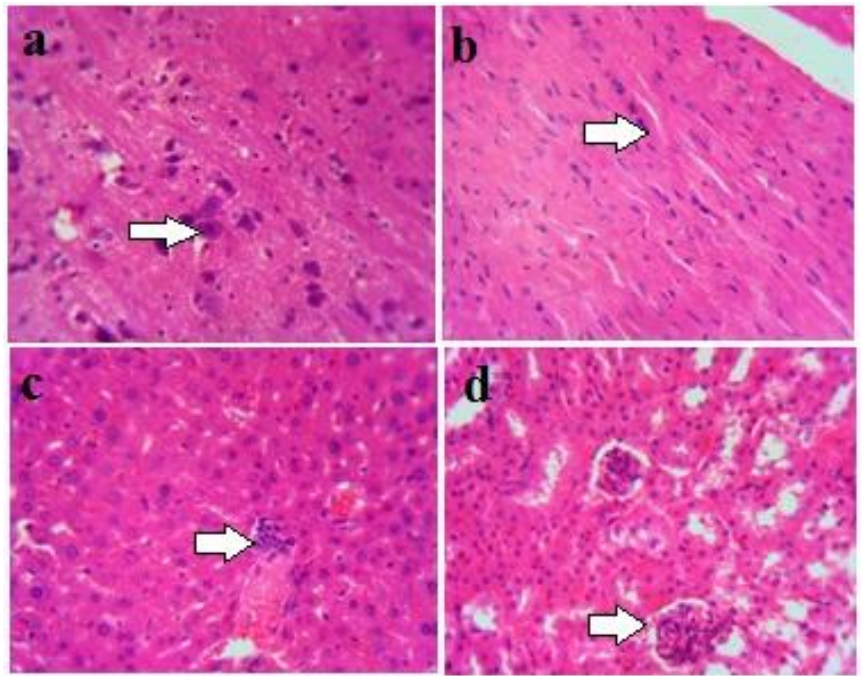

Fig. 2: Effects Of Skin Extract (Pre-Monsoon) On Mice (H\&E X400) a. Gliosis is seen (Brain) 2b. Cardiomyocytes seen in synctial pattern (Heart) 2c. Mild sinusoidal dilations were seen (Liver) 2d. Glomeruli seen with congestion and closely packed tubules (Kidneys).

\section{Effects of Gonads Extract}

Gliosis with haphazardly arranged astrocytes was noticed in the mice brain (Figure 3a). Cardiomyocytes were arranged in synctial pattern in the heart tissues of mice and neither inflammations, nor infections were found (Figure 3b). Liver of mice showed mild to moderate periportal inflammation composed of lymphocytes, plasma cells and few eosinophils (Figure 3c). Glomeruli with congestion were seen in mice kidneys (Figure 3d).

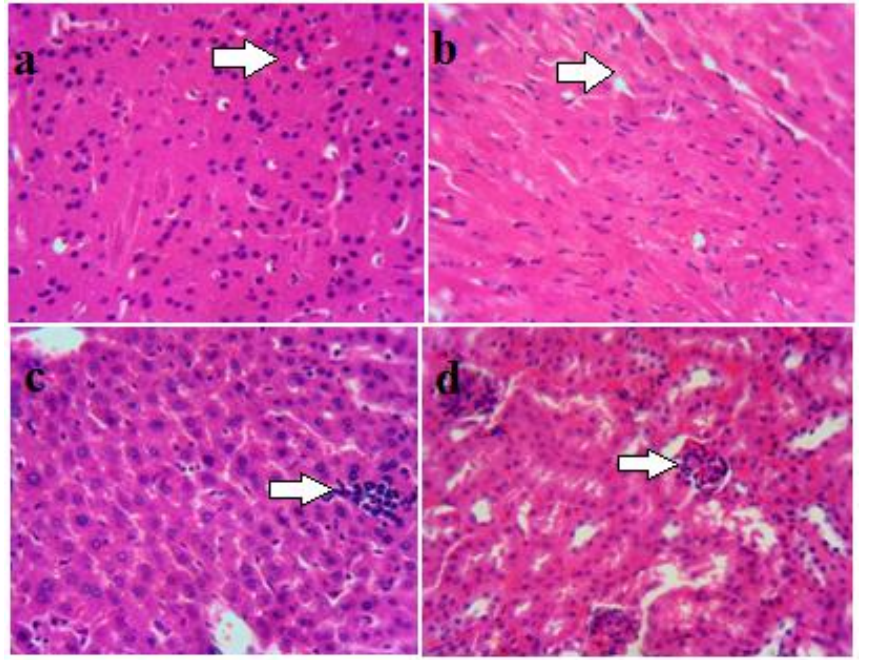

Fig. 3: Effects Of Liver Extract (Pre-Monsoon) On Mice (H\&E X400).

a. Gliosis with haphazard astrocytes seen (Brain) 3b. Cardiomyocytes seen in synctial pattern (Heart) 3c. Moderate periportal inflammation of lymphocytes seen 3d. Glomeruli with congestion seen (Kidneys)

\section{Effects of Skin Extract}

Gliosis was seen and the molecular purkinje layer was observed with intact neurons in the brain of mice (Figure 4a). Cardiomyocytes were arranged in synctial pattern in the heart tissues of mice and neither inflammations, nor infections were found (Figure 4b). Mild periportal inflammations were observed in the liver of mice (Figure 4c). Glomeruli with congestion were seen in mice kidneys (Figure 4d).



Fig. 4: Effects Of Gonads Extract (Pre-Monsoon) On Mice (H\&E X400) a. Gliosis noticed (Brain) 4b. Cardiomyocytes seen in synctial pattern (Heart) 4c. Mild periportal inflammations seen (Liver) 4d. Glomeruli seen with congestion and closely packed tubules (Kidneys). 


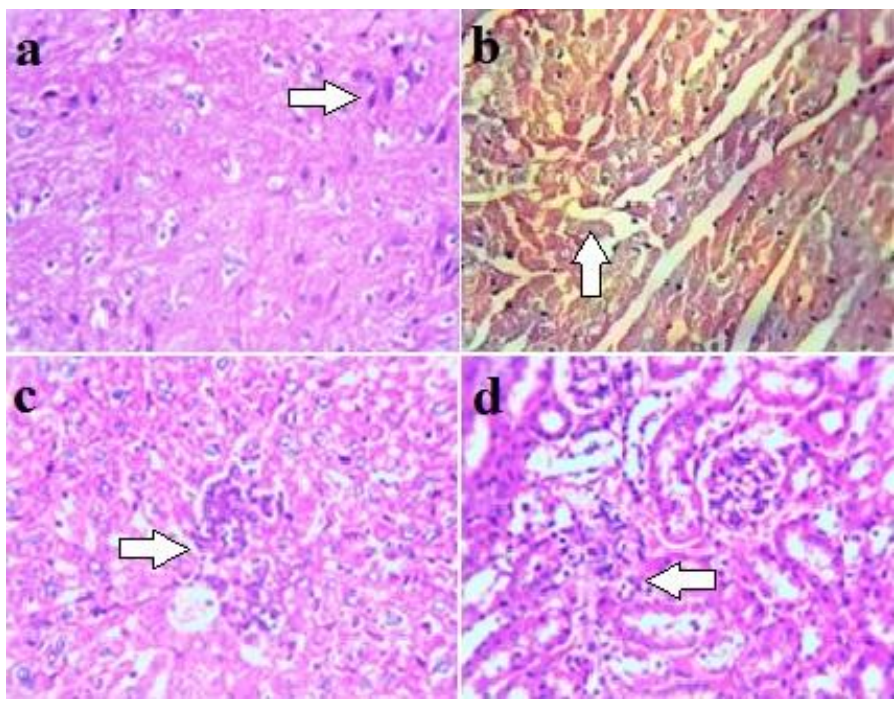

Fig. 5: Effects of Skin Extract (Post-Monsoon) On Mice (H\&E X400). a. Mild vacuolar degenerations found (Brain) 5b. Cardiomyocytes seen in synctial pattern (Heart) 5c. Periportal inflammation and mild congestions seen (Liver) 5d. Glomeruli with hyper cellularity, mild congestions in the interstitia and medulla regions (Kidneys)

\section{Post-monsoon Observations}

\section{Effects of Liver Extract}

Mild vacuolar degenerations were seen in the cerebrum and cerebellum of mice (Figure 5a). Cardiomyocytes were arranged in synctial pattern and no degenerative changes were observed in heart tissues of mice (Figure 5b). Periportal inflammation and mild congestion seen in mice liver (Figure 5c). Kidneys of mice showed glomeruli showed mild hyper cellularity in the cortex region, unremarkable vessels and tubules, mild congestion in the interstitia and mild congestion in the medulla regions (Figure 5d).



Fig. 6: Effects Of Liver Extract (Post-Monsoon) On Mice (H\&E X400). a. Mild vacuolar degenerations seen (Brain) 6b. Cardiomyocytes with mild degenerations in the cytoplasm seen (Heart) 6c. Hepatocytic degenerations and mild congestions seen (Liver) 6d. Unremarkable vessels and tubules with necrosis and apoptosis seen (Kidneys)

\section{Effects of Gonads Extract}

Mild vacuolar degenerations were seen in the cerebrum and cerebellum of mice (Figure 6a). Cardiomyocytes with mild degenerative in the cytoplasm and no hypertrophy, fibrosis, necrosis, inflammation seen in mice heart (Figure 6b). Liver tissue showed degeneration of the hepatocytes, mild congestion and no apoptosis or necrosis (Figure 6c). In the cortex region of kidneys, glomeruli showed mild hyper cellularity, unremarkable vessels and tubules, mild congestion in the interstitia and mild congestion in the medulla regions were observed in the mice injected with liver and gonads extracts (Figure 6d).

\section{Effects of Skin Extract}

No prominent changes were observed in the brain of mice (Figure 7a). Cardiomyocytes with focal vacuolar degeneration and myocardial focal inflammation were seen in heart tissue (Figure 7b). Periportal inflammation and hepatocytic degenerations were observed in mice liver (Figure 7c). Glomeruli showed mild hyper cellularity, mild congestion and tubular degeneration was seen in kidneys (Figure 7d).

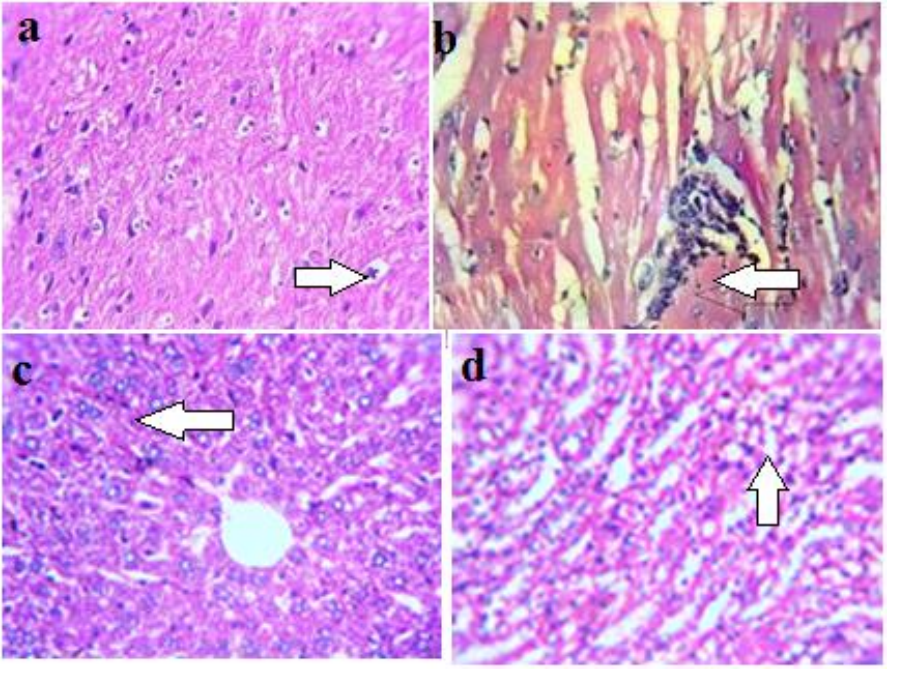

Fig. 7: Effects Of Gonads Extract (Pre-Monsoon) On Mice (H\&E X400) a. No prominent changes observed (Brain) 7b. Cardiomyocytes with vacuolar degeneration and myocardial inflammations seen (Heart) 7c. Periportal inflammation and hepatocytic degenerations found (Liver) $7 \mathrm{~d}$. Glomeruli with hyper cellularity and tubular degenerations seen (Kidneys)

\section{DISCUSSION}

Food intoxications by consumption of pufferfishes is a serious threat in almost all coastal countries. The principle objective of the study was to assess the comparative toxicity of the pufferfish Takifugu oblongus from the coast of Tamil Nadu in different seasons. Collection of specimens was done during three seasons viz, pre-monsoon (March-June), monsoon (July-October) and post-monsoon (November-December), in which there was no availability of the samples in the monsoon season. Pre-monsoon season showed more number of samples when compared to Postmonsoon season. 
Males were predominant over the females. This report is quite juxtaposed with the study done by Ghosh et al., in 2004, which reported that the frequent catch of $T$. oblongus along the Bengal coast was uniform throughout the year and females were predominant. Mouse bioassay revealed that the liver, gonads and skin of the pufferfish are highly lethal causing death of injected mice in few minutes. The muscle extract was completely non toxic showing no symptoms of pufferfish poisoning. In the pre-monsoon season, the toxicity of liver was maximum with $163 \mathrm{MU} / \mathrm{g}$ and skin showing least toxicity with $75.88 \mathrm{MU} / \mathrm{g}$. Phenomenal changes were observed in the post-monsoon season, with gonads exhibiting extreme toxicity of $249.06 \mathrm{MU} / \mathrm{g}$, which may be due to its maturation, and skin showing least toxicity of $89.34 \mathrm{MU} / \mathrm{g}$.

Tani, in 1945 reported that toxicity $\geq 10 \mathrm{MU}$ is considered weakly toxic $(+), \geq 100 \mathrm{MU}$ is moderate $(++)$ and $\geq 1000 \mathrm{MU}$ is strongly toxic (+++), whereas, $<10 \mathrm{MU}$ is considered non- toxic (-). Kawabata in 1978 had reported that toxicity above $10 \mathrm{MU}$ is hazardous for human consumption. This is in slight accordance with the study of Ghosh et al in 2004, which reported that ovaries were toxic than livers of the pufferfish $T$. oblongus, from the coastline of Bengal, in all the seasons.

The toxicity of $T$. oblongus in Taiwan waters was quite similar to that of this study indicating the most toxic organs were liver and ovaries and it varies with the seasons (Hwang et al., 1988; Hwang et al., 1992). Toxicity of the gonads would have increased possibly due to the increase in its weight, maturation and spawning season.

The present study is fairly in accordance with the toxicity of pufferfishes of Hong Kong waters, which follow a seasonal pattern (Yu et al., 2002). In general, TTX is accumulated in the liver, gonads, skin and intestine, as reported by Fuchi et al., in 1991 and Mahmud et al., in 2000. Yet another study by Khora in 1991, reported that skin of the pufferfishes were most toxic. Lee $e t$ $a l$, in 2003 reported that TTX is accumulated in the pufferfishes through their food chain and indeed the toxicity varies depending on this factor too. Khora in 1994 reported that pufferfishes raised in captivity are non toxic. This study clearly shows the toxicity of T. oblongus is possessed in its liver and gonads at the maximum and it varies with the seasons.

\section{CONCLUSION}

Conclusively, the pufferfish $T$. oblongus which has been the cause of food poisoning outbreaks and deaths in most countries proved its seasonal variation in toxicity in its liver and gonads at extremities. Hence, the consumption of this pufferfish species can be avoided to prevent the health hazards not only in the south eastern part of India but also in several other nations. The present study adds detailed data to the toxicity profiling of pufferfishes from India especially from southern India.

\section{ACKNOWLEDGEMENTS}

The authors are grateful to the authorities of VIT University, Vellore, Tamil Nadu, India, for providing the required facilities, their constant encouragement and support.

\section{CONFLICTS OF INTEREST}

The authors hereby declare that we have no conflicts of interest.

\section{REFERENCES}

Ahmed S. Puffer fish tragedy in Bangladesh: an incident of Takifugu oblongus poisoning in Degholia, Khulna. Afr. J. Marine Sci, 2006; 28(2): 457-458.

Chew SK, Goh CH, Wang KW, Mah PK, Tan BY. Puffer fish (Tetrodotoxin) poisoning: clinical report and role of anti-cholinesterase drugs in therapy. Singapore Med J, 1983; 24: 168-171.

Few HD, Noguchi T, Arakawa O, Abe T, Hasimoto K. Toxicological studies on several species of puffer fish in Taiwan. Bull. Jap.Soc. Fish, 1998; 54: 2001-2003.

Fuchi Y, Narimatsa H, Nakama S, Kotobuki H, Hirakawa H, Ohtomo N. Tissue distribution of toxicity in a puffer fish A. Firmamentum. J. Food Hyg. Soc. Jpn, 1991; 32: 530-534.

Ghosh S, Hazra AK, Mitra SK, Mukherjee B. (1993). Poisonous fishes: potential begetter of bioactive substances. In Devadasan K, ed. Nutrients and bioactive substances in aquatic organism. Society of Fisheries Technologists, Cochin: Paico printing press 44-58.

Ghosh S, Hazra AK, Banerjee S, Mukherjee B. The seasonal toxicological profile of four puffer fish species collected along Bengal coast. India. Indian J. Mar. Sci, 2004; 33(3): 276-280.

Hollingworth T, Wekell MM. (1990). Fish and other Marine Products 959.08. Paralytic shellfish poisoning. Biological Method, Final Action. In: Hellrich K, ed. Official Methods of Analysis of the Association of Official Analytical Chemists. Arlington, Virginia 881-882

Homaira N, Rahman M, Luby SP, Rahman M, Haider MS, Faruque LI, Khan D, Parveen S, Gurley E.S. Multiple Outbreaks of Puffer Fish Intoxication in Bangladesh. Am. J. Trop. Med. Hyg, 2010; 83(2): 440-444.

How CK, Chern $\mathrm{CH}$, Huang YC, Wang LM, Lee CH. Tetrodotoxin poisoning. Am. J. Emerg. Med, 2003; 21: 51-54.

Hwang DF, Noguchi T, Arakawa O, Abe T, Hashimoto K. Toxicological Studies on Several Species of Puffer in Taiwan. Nippon Suisan Gakk, 1988; 4(11): 2001-2008.

Hwang DF, Noguchi T, Arakawa O, Abe T, Hashimoto K. Toxicity of puffers in Taiwan. Nippon Suisan Gakk, 1992; 58(8): 15411547.

Jones S. Some deaths due to fish poisoning (Ichthyosarcotoxicism) in India. Indian J. Med. Res, 1956; 42: 353-360.

Kawabata T. 1978. Puffer toxin. In The manual for methods of food sanitation tests II. Environmental Health Bureau, Japan Food. Hyg. Assoc, Tokyo 21-22.

Khora SS. Toxicity studies on puffer fish from tropical waters.

(D. Ag. Thesis). Sendai, Japan: Tohoku University, 1991; 129 p.

Khora SS. 1994. Puffer fish toxins. In: Devdasan K, ed. Nutrients and Bioactive substances in Aquatic organisms. Kochi: Society of Fisheries Technologists 171.

Lange WR. Puffer fish poisoning. Am. Fam. Physician, 1990; 42: 1029-1033.

Lee JH, Kondo H, Sato S, Akimoto S, Saito T, Kodama M, Watabe S. Identification of novel genes related to tetrodotoxin intoxication in pufferfish. Toxicon, 2007; 49: 939-953.

Lefkowitch HJ. 1987. Histopathology of disease, New York, USA: Churchill Living Stone Publisher, pp. 233.

Loke YK, Tam MH. A unique case of tetrodotoxin poisoning. Med J. Malaysia, 1997; 52: 172-174.

Mahmud Y, Noguchi T, Tanu MB, Matsue J. First occurrence of a food poisoning incident due to ingestion of Takifugu oblongus, along with a toxicological report on three marine puffer species in Bangladesh. J. Food. Hyg. Soc. Japan, 1999; 40: 473-80.

Mahmud Y, Arakawa O, Noguchi T. An epidemic survey on freshwater puffer poisoning in Bangladesh, J. Nat. Toxins, 2000; 9: 319326. 
Matsui T, Hamada S, Yamamori K. Local variation of toxicity of puffer fish Fugu niphobles. Bull. Jap. Soc. Jap, 1998; 39: 4321-4425. 20: $67-84$

Narahashi T. Pharmacology of tetrodotoxin. J. Toxicol, 2001;

Tani I. 1945. Toxicological studies of puffers in Japan. Tokyo: Teikoku-Tosho Co 103

Vazquez EJ, Yotsu-Yamashita M, Sierra-Beltran AP, Yasumoto T, Ochoa JL. Toxicities and distribution of tetrodotoxin ion the tissue of puffer fish found in the coast of Baja California Peninsula, Mexico. Toxicon, 2000; 38: 729-734.

Veeruraj A, Arumugam M, Ajithkumar T, Balasubramanian T. Distribution of Tetraodontiformes (Family: Tetraodontidae) along the Parangipettai Coast, Southeast Coast of India. Zootaxa, 2001; 3015: 1-12.

Yang CC, Liao SC, Deng JF. Tetrodotoxin poisoning in Taiwan: an analysis of poison center data. Vet. Hum. Toxicol, 1996; 38: 282-286.

Yoshikawa-Ebesu JSM, Hokama Y, Noguchi T. Tetrodotoxin. (2000). In: Hui YH, Kitts D, Stanfield PG, eds. Food borne disease handbook: Seafood and Environmental toxins. New York: Marcel Deckker 253-285.
Yotsu-Yamashita M. Chemistry of puffer fish toxin. J. Toxicol, 2000; 20: 51-66.

$\mathrm{Yu}$ CF, Yu P.H. The annual toxicological profiles of two common puffer fish, Takifugu niphobles (Jordan and Snyder) and Takifugu alboplumbeus (Richardson), collected along Hong Kong coastal water. Toxicon, 2002; 40: 2001-2003.

\section{How to cite this article:}

Indumathi SM, Khora SS. Seasonal Toxicity Assessment of Oblong Blowfish (Takifugu oblongus) from Tamil Nadu Coast, India. J App Pharm Sci, 2017; 7 (03): 188-193. 